\title{
Entrepreneurial Characteristics and Behaviors of Muntok White Pepper Farmers
}

\author{
Rufti Puji Astuti ${ }^{1}$ (D), Novyandra Ilham Bahtera 1,* (D), \\ and Eddy Jajang Jaya Atmaja ${ }^{1}$ \\ ${ }^{1}$ Department of Agribusiness, Faculty of Agriculture, Fisheries, and Biology, \\ University of Bangka Belitung, 33172 Bangka Belitung Islands, Indonesia \\ * Corresponding Author: novyandra.ib@gmail.com
}

\section{ARTICLE INFO}

\section{Publication Info:}

Research Article

How to cite:

Astuti, R. P., Bahtera, N. I., E Atmaja, E. J. (2019).

Entrepreneurial Characteristics and Behaviors of Muntok White Pepper Farmers. Society, 7(2), 101-115.

DOI : 10.33019/society.v7i2.116

Copyright (C) 2019. Owned by Author(s), published by Society

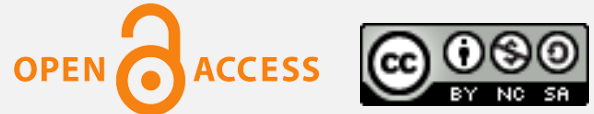

This is an open access article.

License: Attribution-

NonCommercial-ShareAlike (CC BY-NC-SA)

Received: November 7, 2019; Accepted: November 30, 2019; Published: December 20, 2019;

\begin{abstract}
Entrepreneurship is one of the human capital variables of pepper farmers that plays an important role in determining the success of pepper agribusiness development in this creative era. To face the challenges of the business climate change, pepper farmers need entrepreneurship. The objectives compiled in this study are to identify the entrepreneurial characteristics of Muntok White Pepper farmers and to analyze the effect of entrepreneurial characteristics on their entrepreneurial behavior in managing to farm. The study was conducted by survey method, involving 115 farmers. Data analysis used Structural Equation Modeling (SEM) with Partial Least Squares (PLS). The results showed that the entrepreneurial characteristics of pepper farmers are risk-taking, responsive to opportunities, innovative, and motivated. Also, the results showed that the entrepreneurial characteristics of pepper farmers positively and significantly influence their entrepreneurial behavior. Furthermore, the most dominant variable reflecting their entrepreneurial characteristics is the courage to take risks. This study recommends muntok pepper farmers that they always dare to take risks, be persistent and disciplined. Additionally, knowledge and skills need to be constantly updated to grow the ability to innovate and be creative in carrying pepper cultivation activities out.
\end{abstract}




\section{Introduction}

Entrepreneurship has an important role in the development of agribusiness as a practice (Darmadji, 2012). The important role of entrepreneurship is the ability to plan, implement, monitor and evaluate the farming business running.

In 2013, the number of entrepreneurs in Indonesia reached 1.90 percent in which the figure was smaller than neighboring countries such as Malaysia and Singapore which had reached 5 and 7 percent of the total population (Kementerian Koperasi dan Usaha Kecil dan Menengah, 2012). Therefore, the Government of Indonesia continues to strive for growing new entrepreneurs to catch the number of entrepreneurs up, including through the National Entrepreneurship Movement (Indonesian: Gerakan Kewirausahaan Nasional or GKN).

The agricultural sector has a great potential in generating new entrepreneurs considering farmers are the majority of people livelihoods in Indonesia. However, entrepreneurs in the agricultural sector are less well-known compared to other business sectors (Burhanuddin et al, 2018). Entrepreneurial culture is one of the farmer's social capital variables by making them develop and apply technology in managing their farming.

Pepper is one of the export commodities from Indonesia for the international market. Bangka Belitung Islands Province, Indonesia, is one of the largest pepper producing centers which also contributes to supplying Indonesian pepper for export needs. This cannot be separated from the role of the farmers who have persevered in managing the pepper farming business to date. Pepper is cultivated in the form of community plantations involving 54,099 households in the province which mainly is 16,343 households in the South Bangka Regency (Badan Pusat Statistik Provinsi Kepulauan Bangka Belitung, 2013). Pepper produced from the Bangka Belitung Islands Province is known as Muntok White Pepper.

Figure 1

The Average Product of Muntok White Pepper, 1980-2016

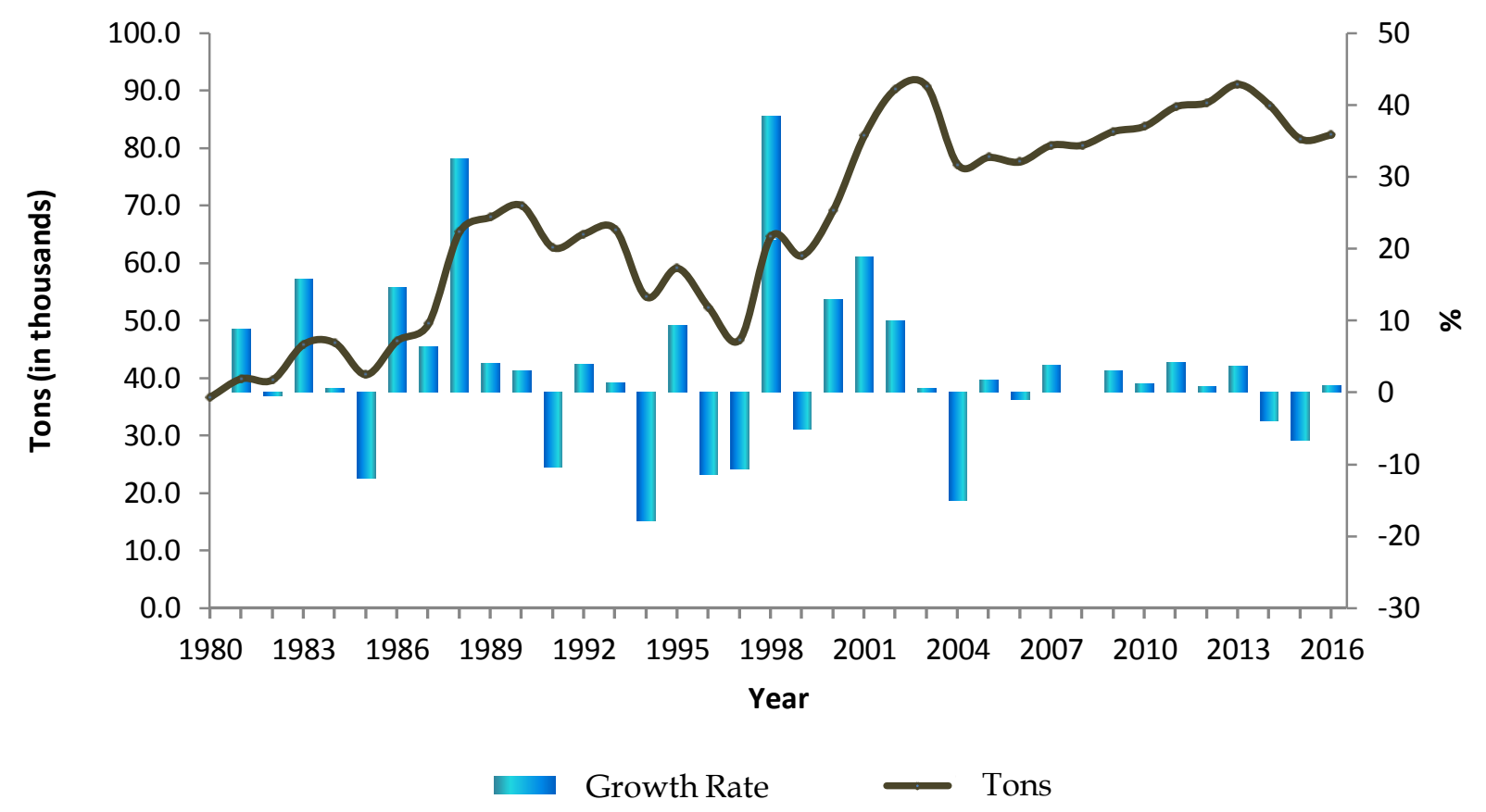

Source: (FAOStat, 2018)

Copyright (C 2019. Owned by Author(s), published by Society. This is an open-access article under CC-BY-NC-SA license. 
The pepper production level takes part in determining the smooth export activity of Indonesian pepper. The availability of pepper supplies is currently facing a problem. The phenomenon of slowing growth of Indonesian pepper production (Figure 1). Many factors cause a decrease in the level of pepper production; soil fertility, disease, and price factor problems. In Bangka Belitung Islands Province, pepper farmers face various obstacles such as the problem of applying cultivation and processing technology to the on-farm agribusiness subsystem. However, pepper farming continues to have endeavored and is the livelihood of most people in Bangka Belitung. Besides, pepper planting activities have also become a hereditary culture. That is the reason, pepper farmers continue to work on their farming business up to now, even prices and disease are hampered.

Behaviors of the farmers in facing obstacles and abilities to survive in responding to prices are the background of this research. Farmer entrepreneurial behavior is focused on the activities of farmers in pepper on-farm agribusiness activities.

Pepper farmers in Bangka Belitung depend on the price of pepper. Slowing production growth (Figure 1) occurs; it means that the prices decline. Recently, the phenomenon is that some farmers have left the pepper farming business and have returned to the tin mining. This indicates that not all pepper farmers are entrepreneur farmers, based on the problem, this research needs to be done on the entrepreneurial characteristics of pepper farmers. The next question that needs to get answer is their entrepreneurial behavior is affected by entrepreneurial characteristics.

Based on the background of the problem, this study aims to identify the entrepreneurial characteristics of pepper farmers and analyze the effect of entrepreneurial characteristics on entrepreneurial behavior.

\section{Literature Review}

Entrepreneurship is a process of applying innovation because of the triggering factors to obtain business growth. Entrepreneurial behavior is part of the process of applying innovation by an entrepreneur (Bygrave \& Zacharakis, 2010). Entrepreneurial behavior is the individual behavior in responding to an opportunity; both through identification and exploitation activities in the context of establishing new businesses and business expansion (Bird, 1996). It is such exploration activities and creating opportunities in managing businesses that are based on entrepreneurial concepts and actions such as showing creativity, innovation and dare to take risks.

Individual behavior can be explained through understanding Fritz Heider's attribution theory which studies how individual behavior is shaped by internal and external factors. Internal factors attribute that is inherent in the nature and quality of personal or personal, on the other hand, external factors come from the environment and situation (in Mustafa, 2011). The general model of entrepreneurial behavior and business performance illustrates that entrepreneurial behavior is determined by two factors, firstly; personal quality. Delmar (1996) provides a general model that explains the factors that determine entrepreneurial behavior such as the model in Figure 2. Therefore, entrepreneurial behavior will be observed from the actions taken by entrepreneurial farmers in managing their agricultural business.

An entrepreneur at least has twelve characteristic traits; (1) achievement motivation, (2) being innovative (3) being creative (4) innovative behavior (5) working seriously (6) persevering and good responsibility, (7) being independent (8) risk-taking propensity (9) responsiveness to opportunities, (10) having leadership skills, (11) having managerial abilities, and (12) having personal abilities (Suharyono, 2017). Entrepreneurial characteristics can be 
explained through variables related to psychological attributes, personality, attitudes, and behavior (Rasheed, 2003 in Ahmad, 2016). Entrepreneurial characteristics become one of the determinant factors of entrepreneurial behavior variables.

Figure 2

The General Model of Entrepreneurial Behavior and Business Performance

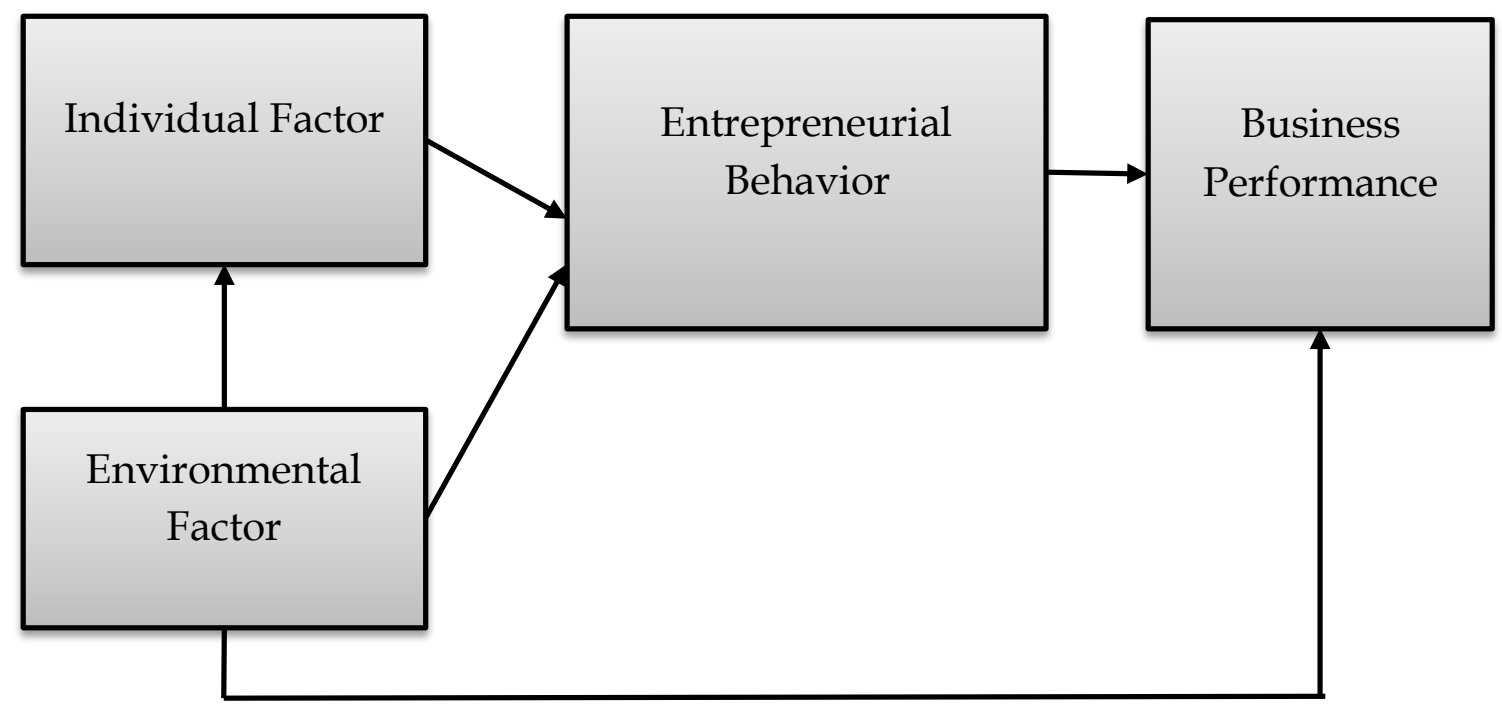

Source: (Delmar, 1996)

The results of previous studies found several indicators of entrepreneurial characteristic variables identified as determinants with entrepreneurial behavior, namely motivation, which is indicated by the need for achievement, taking risk propensity, being initiative and creative, having innovative behavior, self-confidence, and leadership. These factors were identified as determinants with entrepreneurial behavior in the Okiagaru Farm farmer group of Cianjur, West Java Province, Indonesia, while the achievement and self-esteem factors of the weighting results were not significant (Ahmad, 2016). Tempe (fermented soybean in blocks) entrepreneur entrepreneurial behavior in running his business was also formed because of the entrepreneurial characteristics he possessed. The entrepreneurial behavior of the dominant tempe craftsman is shown by cognitive and affective variables and is influenced by the courage to take risks, innovation and the ability to see the opportunities and motivations of tempe craftsmen (Nursiah et al., 2015).

Furthermore, entrepreneurial characteristics of coffee farmers in Lampung, Indonesia, can be seen from seventeen characteristics, namely commitment, drive to achieve, opportunity orientation, initiative, and responsibility, persistent problem solving, seeking feedback, internal locus of control, tolerance for ambiguity, calculating risk-taking, integrity, and reliability, tolerance for failure, high energy level, creativity and innovation, vision, self-confidence and optimism, independence: independent personality, team building, and managerial skills for entrepreneurs. The most dominant entrepreneurial characteristics that characterize coffee farmers in Lampung are the commitment, seeking feedback, integrity and reliability, and tolerance for failure (Burhanuddin, et al., 2018).

The characteristics of entrepreneurship in the form of courage to take risks and motivation are entrepreneurial characteristics known as psychological characteristics in entrepreneurial psychology research. Entrepreneurial psychology emphasizes approaches to personal aspects of 
personality or character. Research into entrepreneurial psychology can contribute to providing results from the types of entrepreneurship based on their psychological characteristics. Hisrich, Langan-Fox, \& Grant (2007) state that the results of this entrepreneurial psychology research can be used to identify potential entrepreneurial seeds, as well as to prepare the required training programs that are appropriate to their psychological character.

\section{Research Methodology}

This section describes the research methodology; the location and time of research, the types and sources of data, the deterministic sampling method and the methods of processing and analyzing data.

\section{A. Place and Time of the Research}

This research was carried out in Bangka Belitung Islands Province by involving pepper farmers of South Bangka, West Bangka, and Central Bangka regencies. The time of the research was six months, from March to August 2019.

\section{B. Type and Source of Data}

The type of data used was primary and secondary data. Primary data obtained from information sources of observation, interviews, and discussions using questionnaires to generate the answers about the characteristics of the farmers both the external environment and entrepreneurial behaviors. Secondary data were obtained from related institutions and literature studies. On the other hand, primary data were obtained from direct interviews guided by a list of questions and a list of answers. Alternative answers are adjusted to the Likert scale 1 to 5 with explanations 1 (Very Disagree), 2 (Disagree), 3 (Neutral), 4 (Agree) and 5 (Very Agree). Secondary data were obtained from the Central Statistics Agency of Bangka Belitung Islands Province.

\section{Deterministic Sampling Method}

The method used was a survey method where the sampling method used simple random sampling. The total number of respondents in this research were 115 farmers.

\section{Design, Processing Method, and Data Analysis}

The data that had been obtained then processed and analyzed both qualitative and quantitative descriptive. Quantitative data analysis was performed using Structural Equation Modeling (SEM) by using smart partial least squares (PLS). The reason for using SEM due to it can describe all correlations between constructs in the form of a direct model (Wijanto, 2008). Data analysis using SEM PLS involved two variables namely endogenous latent variables of entrepreneurial behavior and exogenous latent characteristics of entrepreneurship that were observed through variable indicators (Table 1). 
Table 1

Research Variables

Manifest Variables

Description

Entrepreneurial characteristics (KW)

\begin{tabular}{|c|c|}
\hline Innovative / INOV(X1.1) & $\begin{array}{l}\text { The frequency and willingness to make changes in } \\
\text { running a business }\end{array}$ \\
\hline Risk-taking propensity / RSKO (X1.2) & $\begin{array}{l}\text { Courage in facing production, investment, financial } \\
\text { risks. }\end{array}$ \\
\hline Entrepreneurial motivation / MOTV (X1.3) & $\begin{array}{l}\text { An underlying individual motivation to be an } \\
\text { entrepreneur }\end{array}$ \\
\hline $\begin{array}{l}\text { Responsiveness to opportunities / TGTP } \\
\text { (X1.4) }\end{array}$ & $\begin{array}{l}\text { The ability to recognize opportunities or be oriented } \\
\text { to opportunities }\end{array}$ \\
\hline Experience / PGLM (X1.5) & The duration of running a business \\
\hline Independence / MDRI (X1.6) & $\begin{array}{l}\text { Independent work/running own business or not an } \\
\text { employee/ working in government institutions }\end{array}$ \\
\hline \multicolumn{2}{|l|}{ Entrepreneurial Behavior (PK) } \\
\hline Affective / AFEK (Y1.1) & $\begin{array}{l}\text { The attitude is shown by running business } \\
\text { (disciplined, persistent and having a deep } \\
\text { commitment do business }\end{array}$ \\
\hline Cognitive / KOG (Y1.2) & Ability in running a business \\
\hline Motoric / MOT (Y1.3) & $\begin{array}{l}\text { An individual skill (entrepreneur) in running a } \\
\text { business (ability take chances, face risks, creativity } \\
\text { and innovative) }\end{array}$ \\
\hline
\end{tabular}

Figure 3 below illustrates the overall design of the research model

Figure 3

Cross Diagram Model on Characteristics and Behaviors of Muntok White Pepper Farmers

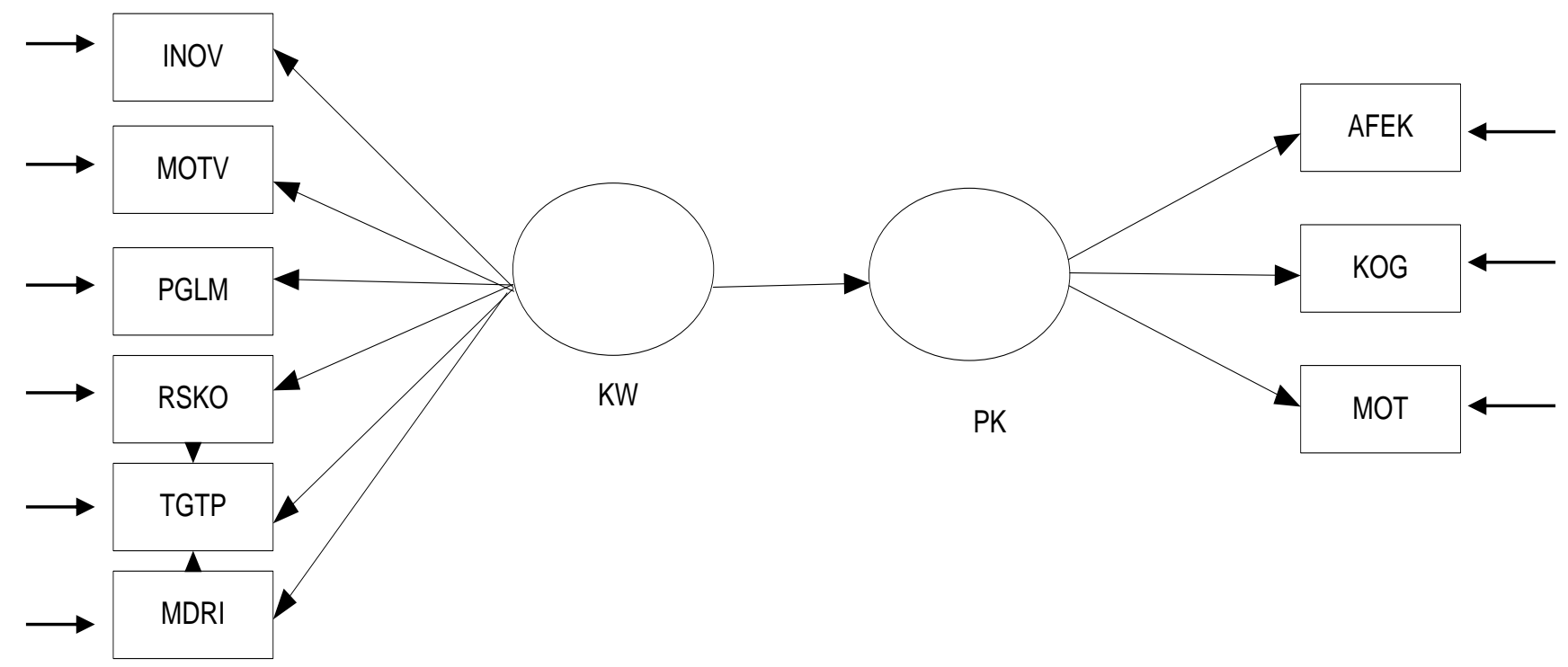

Copyright (C 2019. Owned by Author(s), published by Society. This is an open-access article under CC-BY-NC-SA license. https://doi.org/10.33019/society.v7i2.116 
The data analysis process was carried out through two stages, namely the model analysis stage or Outter Model analysis and the Inner Model analysis. Outer Analysis Model serves to explain the relationship between indicator variables (manifest) with latent variables, meanwhile, the Inner Model analysis explains the relationships between latent. Evaluation of the measurement model is done by looking at the Loading Factor value $(\lambda)$. The indicator used is said to be valid if it has a Loading Factor value $(\lambda)$ greater than 0.5 . The next step in evaluating the structural model is the significance test based on the estimated value of the path parameter coefficient. Significance tests for the estimated parameter path coefficients in SEMPLS, performed using resampling methods such as bootstrapping. Mathematically the formulation of structural equation equations in this study is formulated as follows:

1) Structural Equation Modeling

PK $\quad(\eta 1)=\gamma_{\mathrm{kw}} \xi_{\mathrm{kw}}+\varsigma 1$

2) The Measurement Model of Endogenous Latent Variables

$\mathrm{PK}=\lambda_{\mathrm{KW}} \eta 1+\varepsilon 1$

3) The Measurement Model of Exogenous Latent Variables

$\mathrm{INOV}=\lambda_{\text {inov }} \xi 1+\delta 1$

MOTV $=\lambda_{\text {motv }} \xi 2+\delta 2$

$\mathrm{RSKO}=\lambda_{\text {rsko }} \xi 3+\delta 3$

TGTP $=\lambda_{\text {tgtp }} \xi 4+\delta 4$

$\mathrm{AFEK}=\lambda_{\mathrm{afek}} \xi 5+\delta 5$

$\mathrm{KOG}=\lambda_{\mathrm{kog}} \xi 6+\delta 6$

MOT $=\lambda_{\text {mot }} \xi 7+\delta 7$

$\eta 1=$ endogenous latent variable of entrepreneurial behavior

$\gamma=$ regression coefficient of the structural equation model

$\varsigma \quad=$ error component model

$1, \mathrm{n}=$ exogenous latent variable of entrepreneurial characteristics

$\lambda=$ loading factor of indicator variable in exogenous and endogenous latent

$\delta, \varepsilon=$ error in the regression model of the indicator variable

\section{Results and Discussion}

\section{A. Measurement Model Evaluation}

Evaluating the loading factor is the first step that must be done in evaluating the measurement model using SEM PLS. The loading factor value of the evaluation results becomes a benchmark in assessing the goodness of the model. Indicator variables that have a loading factor $(\lambda)$ value less than 0.5 cannot be used in the analysis; as a result, it is necessary to carry out the stage of verification models. The results obtained from the PLS algorithm in the research model show that all indicators used are valid and reliable based on evaluation criteria in the PLS measurement model (Figure 4). 
Figure 4

Standardized Loading factor

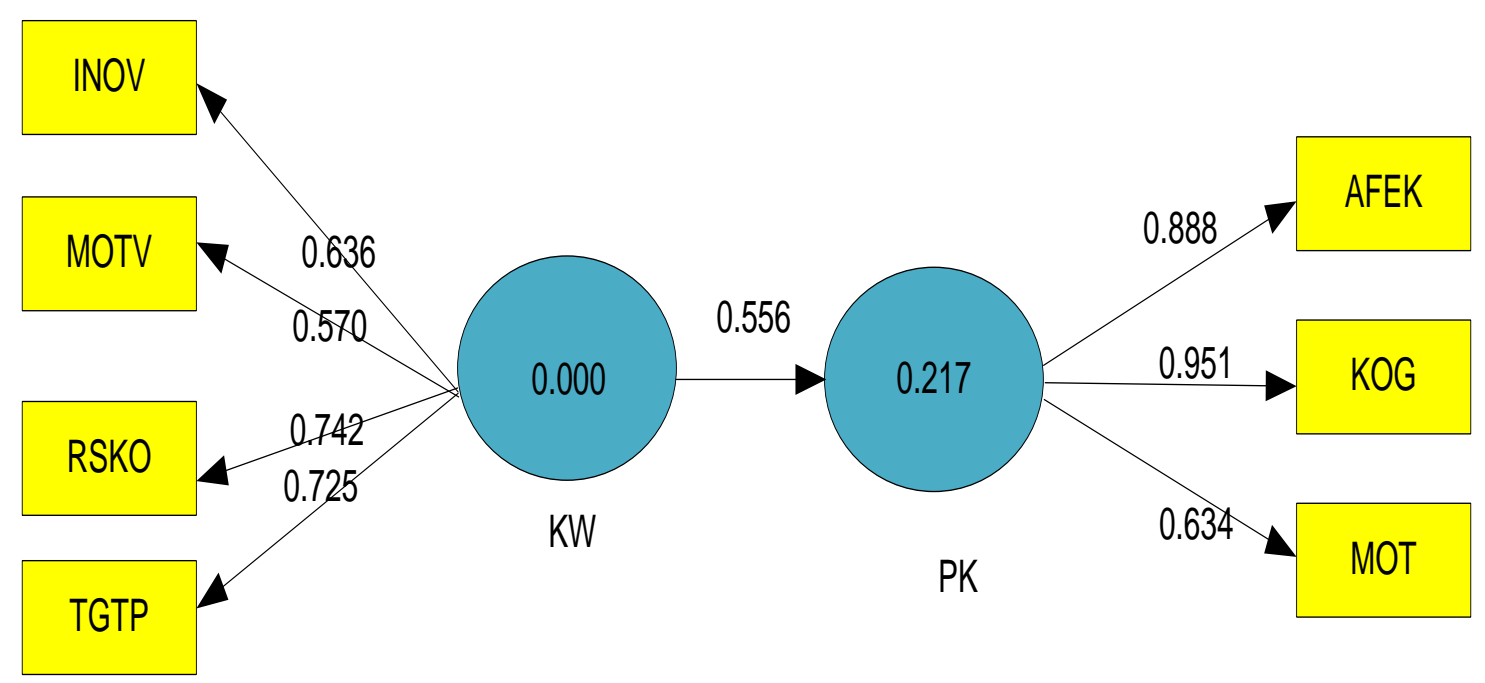

\section{B. Structural Model Evaluation}

The purpose of evaluating the structural model is to look at the relationship between latent constructs by looking at the estimated results of the path parameter coefficient and the level of significance (Ghazali, 2006). The next step in evaluating the structural model is to test the significance of the relationship between latent variables. Significance tests for the path parameter coefficients in SEM-PLS are using the resampling method. The estimation results both in the path parameter coefficient and the significance test are then used to test the hypothesis. Significance tested results of all hypotheses built in this study can be seen in Table 1.

\section{Entrepreneurial Characteristics of Muntok White Pepper Farmers}

Entrepreneurial characteristics are the individual factors that determine the entrepreneurial behavior of pepper farmers in conducting cultivation activities. Entrepreneurial characteristics are internal factors that are formed scientifically or due to environmental influences. The entrepreneurial characteristics of pepper farmers are observed from four observational variables, namely: innovation, risk-taking, motivation and the ability of farmers to respond to opportunities (Dirlanudin, 2010; Alma 2010; Puspitasari 2013).

Table 2

Contribution of Entrepreneurial Characteristic Indicators based on Loading Factor Dan T-Value

\begin{tabular}{|c|ccc|} 
Latent Variable & Manifest Variable & Loading Factor & T-Value \\
\hline \multirow{3}{*}{ Entrepreneurial } & Innovation & 0.635 & 2.528 \\
\cline { 2 - 4 } Characteristics & Motivation & 0.569 & 2.134 \\
\cline { 2 - 4 } & Risk-taking & 0.742 & 2.663 \\
\cline { 2 - 4 } & Responsiveness to Opportunities & 0.725 & 3.263 \\
\hline
\end{tabular}


The results of the SEM-PLS analysis of the model show that the indicators of innovation, risk-taking, motivation, and the ability of farmers to respond to significant opportunities contribute to reflecting the entrepreneurial characteristics of pepper farmers. The loading factor value obtained by each indicator variable and $t$-value is greater than 0.5 and 1.96. The factor loading values of the indicator variables for innovation, risk-taking, and responsiveness to opportunities in Table 1 are $(\lambda=0.635 ; 0.569 ; 0.742 ; 0.725)$. That is, the entrepreneurial characteristics of pepper farmers can be seen from 4 characters namely the willingness to innovate, have the motivation, dare to take risks and be responsive to opportunities.

Entrepreneur farmers are those who carry out farming activities by utilizing business opportunities in the agricultural sector so that they act as farmers as well as entrepreneurs. The majority of farmers carry out farming activities in rural areas. This has an impact on the emergence of the problem of limited access, which until now is still an obstacle in the formation of entrepreneurial farmers. At present, rural farmers still need tangible solutions to have the capacity to become entrepreneurial farmers.

Pepper growers have entrepreneurial characteristics that are risk-taking. Based on the factor loading values obtained in Table 2 shows that the courage to take risks is the strongest indicator variable contributing to reflecting the entrepreneurial characteristics of pepper farmers. The development of entrepreneurial farmers, according to Burhanuddin et al., (2018) needs to be supported by the existence of entrepreneurial skills (entrepreneurial skills). An entrepreneur is someone who has the personal power to deal with environmental changes and also dares to take risks. This shows that based on the characteristics of entrepreneurship, it can be said that white pepper farmers are entrepreneur farmers.

As a characteristic, the courage to take risks shows the ability of farmers to stay afloat in managing pepper farming by showing a tolerant attitude towards various forms of failure. Courage to take risks is reflected in the ability of farmers to manage their farming until the time of research, despite the problem of price and disease. Farmers are also not afraid to increase the planting area even though the selling price of pepper is getting cheaper or the input price is expensive. This shows that with an average of 14 years of experience managing farming, pepper farmers are people who never give up, have a willingness to learn, be realistic in facing difficulties and see failure as a form of the learning process. One way farmers face risk and survive managing their farming by taking risks. However, 83.95 percent of farmers agreed to strongly agree that in addition to taking the risk, farmers also tried to reduce the risk by controlling disease attacks through the application of technology. This is why farmers can survive in the cultivation of pepper.

The same results were also found in the case of tempe (fermented soybean in blocks) craftsmen in Bogor Regency and coffee farmers in Lampung. The tempe producers have entrepreneurial characteristics that are brave to take risks which are shown from the spirit of staying in business and increasing the amount of production without fear of products not being marketed even though soybean prices as the main production input have increased prices (Nursiah et al., 2015). Coffee farmers in Lampung also have a tolerant character to various forms of failure during 17 years of managing coffee farming. Coffee farmers are realistic enough to see difficulties and are not easily disappointed, and continue to learn from the various failures experienced. According to Burhanuddin et al., (2018) that the tolerant character of failure is a driving factor for farmers' ability to continue to carry out coffee cultivation as the main farming commodity.

White pepper farmers also have characteristics of responsiveness to opportunities. The responsive character of this opportunity shows that the ability of farmers to see and assess

Copyright (C 2019. Owned by Author(s), published by Society. This is an open-access article under CC-BY-NC-SA license.

https://doi.org/10.33019/society.v7i2.116 
opportunities as an opportunity so that farmers can take advantage of each opportunity that provides a potential advantage for pepper cultivation activities undertaken. Examples of forms of action farmers take advantage of opportunities can be seen from changes in cultivation activities by replacing the use of seed types. As many as 51.75 percents of farmers agreed to the point that strongly agreed that the assistance of one-section cuttings seedlings provided an opportunity for farmers to contribute to implementing the technology.

The ability of farmers to be responsive to opportunities is also a factor driving farmers to continue carrying out pepper cultivation activities. Pepper farmers' contribution in applying one-segment seed technology is not only based on the assistance of free seedlings, but farmers are also trying to learn and improve the ability to make one-section cuttings seedlings by attending training in field schools. That is, the existence of a field school program for pepper farmers can be used as an opportunity to increase knowledge and skills. The form of responsive actions to opportunities is also shown by the attitude of farmers choosing to join or form farmer groups to have the opportunity to be actively involved in training activities so that they get advisory assistance. However, the benefits of the field school program as an opportunity have not been widely felt by farmers because only 25.3 percent of farmers agree that attending a field school can provide opportunities to implement the technology.

Innovation is also an entrepreneurial characteristic of muntok white pepper farmers. The form of pepper farmers' innovation actions is reflected in the urge to make changes in pepper cultivation activities. The urge to make changes is observed from the frequency of pepper farmers making changes and the forms of changes made. That is, the characteristics of the innovation of pepper farmers in this study are only as users of innovation rather than creators of innovation. Innovations have been made by pepper farmers with an average frequency of changes of more than twice. The change made by pepper farmers is reflected in changes in the use of input types only, while efforts for product innovation have not been made. Changes in the use of input types are reflected in changes in the use of types of seeds and climbing poles while changes in the use of fertilizers have not been done much.

Innovations by pepper farmers show that the ability to apply or use new methods of production. Changes in the use of production input types by pepper farmers indicate that the form of innovation carried out by farmers occurs in the application of new methods of production. The results of research Astuti et al., (2016) found that innovation is a characteristic of farmers who form the entrepreneurial activities of broiler breeders. The adoption of new methods of production is done by breeders as a form of innovation by doing better things. Farmers choose to switch to using the type of production inputs, namely seedlings. Innovation is also an entrepreneurial characteristic of tempe (fermented soybean in blocks) craftsmen in Bogor. Not only make changes in using new methods in production, but tempe (fermented soybean in blocks) craftsmen also innovate products of both types and sizes. The application of new methods of production by tempe (fermented soybean in blocks) artisans is done by switching to the form of equipment used (Nursiah et al., 2015).

Motivation is an entrepreneurial characteristic that shows personal nature. Motivation in this study is interpreted as the desire or need of farmers to act certain to achieve their goals. Farmer motivation is a social value that plays an important role in determining farmers' entrepreneurship. Suryana (2003) suggested that motivation for achievement is a social value that emphasizes the desire to achieve satisfaction. Motivation theory explained by Maslow in Suharyono (2017) explains that a person's motivation is formed because of the need, both physiological needs, security needs, esteem needs, and self -actualization needs.

Copyright (C 2019. Owned by Author(s), published by Society. This is an open-access article under CC-BY-NC-SA license. 
Pepper farmers have the desire to achieve success in farming. Not a few farmers have a motive for achievement to survive while running farming activities and preserving the culture of pepper cultivation. The motivation of pepper growers in this study was observed from the willingness to keep on learning from the experience, involvement, and participation of farmers in various training related to farming and applying new methods related to pepper cultivation techniques. Based on the factor loading values obtained, Table 1 shows that indicators of motivation variables contribute to reflecting the entrepreneurial characteristics of farmers. However, the factor loading value obtained $(\lambda=0.569)$ is considered to be still low so that the contribution of motivational indicator variables in reflecting the entrepreneurial characteristics of pepper farmers is the weakest. Pepper farmers lack the motivation to excel in conducting pepper cultivation activities. The form of action to do better is not done by all farmers and only as farmers who are actively involved in various training and extension activities. Pepper cultivation activities undertaken by farmers are only partly based on the desire to continue to preserve the culture of planting pepper.

Forms of action that are better than before indicating the existence of motivation for achievement in an entrepreneur. Characteristics of entrepreneurs who have the motivation that is having the desire to overcome various difficulties encountered and have the courage to take risks with full calculation (Suryana, 2003). While Darmadji (2012) explained that the need for achievement as an indicator of motivation is characterized by a willingness to learn from failure, participation in efforts to increase production, implementation of new methods related to cultivation, and involvement in extension activities and training related to farming.

\section{Characteristic Influences on Entrepreneurial Behaviors}

Individual behavior can be explained through understanding Fritz Heider's attribution theory which studies how individual behavior is shaped by internal and external factors or the environment. The entrepreneurial behavior of farmers in this study only covers the behavior of farmers in on-farm pepper agribinis or cultivation subsystems. The identification of pepper farmer entrepreneurial behavior is based on the entrepreneurial theory that explains how social groups respond differently to a business opportunity and can shape entrepreneurial behavior.

Table 3

Path Coefficient Value

\begin{tabular}{|cccc|}
\hline Hypotesis & Original Sample & T-Value & Conclusion \\
\hline KW -> PK & 0.246 & 2.582 & Significant \\
\hline
\end{tabular}

$t(0.05) ; 1.96$

The results of the path parameter coefficient analysis in Table 3 show that entrepreneurial characteristics have a direct and positive influence on the entrepreneurial behavior of pepper farmers in pepper cultivation business activities. The latent variable of entrepreneurial characteristics significantly contributed to forming entrepreneurial behavior with the acquisition of a $2.582 \mathrm{t}$-value greater than 1.96. Tempe (fermented soybean in blocks) entrepreneurship entrepreneurial behavior in running its business was also formed due to the entrepreneurial characteristics it possessed (Nursiah et al., 2015). 
Entrepreneurial characteristics are one of the factors that determine entrepreneurial behavior through a process. The influence of entrepreneurship characteristics on entrepreneurial behavior is explained through one of the indicator variables identified as a determinant factor in entrepreneurial behavior, namely the courage to take risks (Ahmad, 2016). Entrepreneurial behavior is formed and can be observed directly or indirectly (Bygrave, 1991). Entrepreneurial behavior is formed through a process of encouragement from cognitive, affective and psychomotor components. It can be concluded that the process of the formation of entrepreneurial behavior involves elements that can be directly observed or not from an entrepreneur. The component of knowledge (cognitive) and mental attitude (affective) are elements that cannot be observed directly while the element of skill (psychomotor) can be observed directly by an entrepreneur (Bird, 1996).

\section{Table 4}

Contribution of Entrepreneurial Behavior Indicators based on Loading Factor and T-Value

\begin{tabular}{|cccc|} 
Latent Variable & Manifest Variables & Loading Factor & T-Value \\
\hline \multirow{2}{*}{$\begin{array}{c}\text { Entrepreneurial } \\
\text { Behaviors }\end{array}$} & Affective & 0.887 & 19.188 \\
\cline { 2 - 4 } & Cognitive & 0.950 & 41.085 \\
\cline { 2 - 4 } & Motoric & 0.633 & 5.546 \\
\hline
\end{tabular}

The results of the analysis of entrepreneurial behavior with the SEM-PLS on the model show that the affective, cognitive, and motor indicator variables together significantly contribute to reflecting the entrepreneurial behavior of pepper farmers (Table 4 ). Affective and cognitive indicators have the greatest loading factor values $(\lambda=0.887$ and $\lambda=0.950)$. The findings in the study also showed that between the two types of elements forming entrepreneurial behavior it was seen that the entrepreneurial behavior of pepper farmers was more formed from elements that could not be directly observed, namely attitudes and knowledge. This is because the value of the loading factor of the two indicators tends to be greater than the motor indicator $(\lambda=0.633)$. The same results were also found in the research on entrepreneurship behavior of tempe (fermented soybean in blocks) craftsmen in Bogor, West Java Province, Indonesia. The entrepreneurial behavior of tempe (fermented soybean in blocks) artisans is reflected by the contribution of the affective, cognitive, and motor indicator variables (Nursiah et al., 2015). The entrepreneurial behavior of pepper farmers and tempe (fermented soybean in blocks) artisans is greater reflected by the contribution of cognitive indicator variables.

Entrepreneurial cognition is the knowledge structures that people use to conduct assessments, assessments and make decisions, which involve evaluating opportunities, creating and developing businesses (Hisrich et al, 2007). The entrepreneurial behavior of pepper farmers is dominantly formed from cognitive indicators, due to the statement of farmers that to achieve success in pepper cultivation business activities, knowledge is needed that can be used to develop businesses. Based on the results of interviews conducted, not a few farmers stated that the knowledge they had was obtained not only from the experience of farming but also from the empowerment of pepper farmers through counseling and training. Farmers are also trying to find information to increase knowledge, one of the efforts is to join a group of farmers. The same results were also found in the case of tempe (fermented soybean in blocks) craftsmen in 
Bogor, that cognitive (knowledge) that characterizes the behavior of tempe (fermented soybean in blocks) craftsmen in Bogor, namely entrepreneurial knowledge in conducting business such as entrepreneurs must be able to manage businesses efficiently, conduct information search, and understand the importance of education in supporting knowledge entrepreneurship (Nursiah et al, 2015).

Knowledge is interpreted by many previous experts as a person's condition obtained from various sources such as experience, vision, and hearing (Tart, 1971 and Notoatmodjo, 2003 in Ardi, 2015). Knowledge is also interpreted as a psychological process, related to memories to understand, comprehend and live (Herman Hudojo, 2003). The form of farmers' knowledge that reflects entrepreneurial behavior, that is, farmers understand and understand that farming must be managed with basic knowledge of cultivation techniques, tillage in land preparation, fertilization and crop maintenance. Farmers also agreed that production risk can be reduced by taking into account soil moisture, land cleanness and ensuring that the land used is not used as diseased cropland, and using pesticides wisely and on a scheduled basis. This means that the knowledge possessed makes farmers able to be tolerant of risk. Tolerance towards risk according to Hisrich et al (2007) that being one of the unique characteristics of entrepreneurs, it should not only be brave or happy to face risk, how entrepreneurs' perceptions of risk also need to be considered, because the perception of risk can make entrepreneurs more tolerant of risk. Knowledge about terracing, fertilizing, land management, plant maintenance, land maintenance, has a positive influence on farmers' attitudes on arable land. This knowledge is also significant and has a positive effect on the farmer's behavior (Ardi, 2015).

Farmers behave entrepreneurially in carrying out pepper cultivation business activities. Farmer entrepreneurial behavior is reflected by the attitude of discipline and persistence of farmers. Pepper growers show a disciplined attitude and persistence in the activities of fertilizing, harvesting and trimming the chalk done on time. Pepper farmers also seek discipline in the use of capital and continue to persevere in controlling plant diseases and pests. The form of entrepreneurial behavior of pepper farmers is also shown by the use of live climbing poles in pepper cultivation activities. The use of live climbing poles is not a problem because armed with the knowledge possessed by farmers can overcome the problem of using an ineffective climbing pole along with farmer discipline in the activity of canopy pruning.

According to Setianan (2005), the affective variable indicator is a person's attitude in responding to a social phenomenon that can influence people's behavior. A person's attitude can characterize whether he is an entrepreneur or not. Entrepreneurial behavior is not only characterized by attitude but also needs to be accompanied by knowledge and skills. The results of the study found a weak contribution from the variable skills (motor). Pepper growers show forms of entrepreneurial behavior from the (motor) skills used to innovate. However, innovation is only limited to changes in the use of new ways of production by replacing the use of input types. The innovations that have been made are not product-oriented, where the goal is limited to survival, reducing the risk of pest attack, the efficiency of production costs, and increasing the amount of production.

Existing character in an individual influence entrepreneurial behavior through the encouragement which can then shape one's attitude in acting, gain one's knowledge in carrying out business activities, and have skills in producing products. Nursiah et al., (2015) states that entrepreneurial behavior by an entrepreneur can affect the results of the performance of a business that is run. Farmer entrepreneurial behavior can continue to grow and be developed where one way that can be done is by increasing the motivation of farmers (Puspitasari, 2013).

Copyright (C 2019. Owned by Author(s), published by Society. This is an open-access article under CC-BY-NC-SA license. 


\section{Conclusions}

Pepper farmers have dominant entrepreneurial characteristics and behaviors. It is reflected by the characteristics of the courage to take risks and the ability to respond to opportunities. The entrepreneurial characteristics of pepper farmers also found in this study are the motivation and innovation of farmers. The entrepreneurial characteristics positively and significantly influence the entrepreneurial behavior of farmers. This study also found that the entrepreneurial behavior of pepper farmers is shown by affective, cognitive and motoric actions. The courage of farmers to take risks, respond to opportunities, the willingness to innovate and have the motivation to influence the attitudes, knowledge, and skills that are demonstrated through real actions of farmers in conducting pepper cultivation activities. This study suggests that pepper farmers always dare to take risks, be persistent and disciplined. Besides, knowledge and skills need to be constantly updated to grow the ability to innovate and be creative in carrying out pepper cultivation activities.

\section{Acknowledgement}

The authors would like to thank the Directorate General of Research Strengthening and Development for funding support and facilities for making this study a success through Beginner Lecturer Research Grant Scheme (Indonesian: Hibah Penelitian Dosen Pemula (052/SP2H/LT/DRPM/2019)), awarded by the Ministry of Research, Technology and Higher Education of the Republic of Indonesia, Decree Number 7/E/KPT/2019. The Authors also like to thank the Institute of Research and Community Service (Indonesian: Lembaga Penelitian dan Pengabdian kepada Masyarakat or LPPM) the University of Bangka Belitung for pleasant administration to support us during this study conducting.

\section{References}

Ahmad, M. Y. (2018). Identifikasi Faktor Determinan Perilaku Kewirausahaan Pada Kelompok Tani Okiagaru Farm, Desa Ciputri, Kecamatan Pacet Kabupaten Cianjur. Agroscience, 6(1), 37-43.

Alma, B. (2010). Kewirausahaan Edisi Revisi. Bandung: Alfabeta.

Ardi, M. (2015). Perilaku Petani Tegalan Dalam Meningkatkan Kualitas Lingkungan Di Kabupaten Soppeng. Indonesian Journal of Fundamental Sciences, 1(1).

Astuti, R. P., Pambudy, R., \& Burhanuddin, B. (2016). Dampak Tata Ruang Wilayah Terhadap Aktivitas Kewirausahaan Dan Pertumbuhan Usaha Peternakan Ayam Broiler Di Provinsi Jambi. TATALOKA, 18(2), 67-75.

Badan Pusat Statistik. (2013). Data Sensus Pertanian Provinsi Bangka Belitung. Pangkalpinang: Badan Pusat Statistik Provinsi Bangka Belitung.

Bird, M. J. (1996). Entrepreneurial Behavior. Singapore: Irwin Mc Graw Hill.

Bosma, N., Wennekers, S. \& Amorós, J. E. (2011). Extended report: Entrepreneurs and entrepreneurial employees across the globe. London (GB): Global Entrepreneurship Research Association.

Burhanuddin, B., Pambudy, R., \& Wahyudi, A. F. (2019). Analisis Karakteristik Kewirausahaan dan Adopsi Inovasi Petani Kopi di Provinsi Lampung. Jurnal Agribisnis Indonesia, 6(2), 7384 .

Burhanuddin. (2014). Pengaruh Aktivitas Kewirausahaan Peternak Ayam Broiler Terhadap Pertumbuhan Bisnis Peternakan di Indonesia. Disertasi. Bogor: Sekolah Pasca Sarjana Institut Pertanian Bogor. 
Bygrave, W. D., \& Zacharakis A. (2010). The Portable MBA in Entrepreneurship: Fourth Edition. New Jersey: John Willey \& Sons Inc.

Darmadji, D. (2012). Analisis Kewirausahaan Petani. Agrika: Jurnal Ilmu-Ilmu Pertanian, 6(1).

Dirlanudin. (2010). Perilaku Wirausaha dan Keberdayaan Peng.usaha Kecil IndustriAgro: Kasus di Kabupaten Serang Provinsi Banten. Disertasi. Bogor : Institut Pertanian Bogor.

Delmar, F. (1996). Entrepreneurial Behavior and Business Performance. Dissertation. Stockholm: Ekonomiska Forknings Institute.

Ghozali, I. (2006). Struktural Equation Modeling: Metode Alternative dengan Partial Least Square. Semarang: Badan Penerbit Universitas Diponegoro.

Hisrich, R., Langan-Fox, J., \& Grand, S. (2007). Entrepreneurship research and practice: A call to action for psychology. American Psychologist, 62(6), 575-589.

Kementrian Koperasi dan Usaha Kecil dan Menengah Republik Indonesia. (2012). Jumlah Unit Usaha UMKM. Retrieved 8 8, 2019, from www.depkop.go.id.

Mustafa, H. (2011). Perilaku Manusia dalam Perspektif Psikologi Sosial. Jumal Administrasi Bisnis, 7(2).

Nursiah, T., Kusnadi, N,. \& Burhanuddin, B. (2015). Perilaku Kewirausahaan pada Usaha Mikro Kecil (UMK) Tempe di Bogor Jawa Barat. Jurnal Agribisnis Indonesia, 3(2), 145-158.

Puspitasari. (2013). Pengaruh perilaku kewirausahaan petani anggrek terhadap kinerja usaha: Kasus di Kecamatan Gunung Sindur dan Parung, Kabupaten Bogor, dan Kecamatan Serpong, Kota Tangerang Selatan. Tesis. Bogor: Institut Pertanian Bogor.

Setiana, L. (2005). Teknik Penyuluhan dan Pemberdayaan Masyarakat. Bogor: Ghalia Indonesia.

Suharyono, S. (2017). Sikap dan Perilaku Wirausahawan. Jurnal Ilmu dan Budaya, 40(56).

Suryana. (2003). Memahami Karakteristik Kewirausahaan. Jakarta: Direktorat Jenderal Pendidikan Dasar dan Menengah Departemen Pendidikan Nasional Republik Indonesia.

Wijanto, S. H. (2008). Structural Equation Modelling dengan Lisrel 8.8: Konsep dan Tutorial. Yogyakarta: Graha Ilmu.

\section{About The Authors}

1. Rufti Puji Astuti, is an Assistant Professor at Department of Agribusiness, University of Bangka Belitung, Indonesia. She graduated from IPB University, Bogor, Indonesia, 2016. E-Mail: ruftipuji24@gmail.com.

2. Novyandra Ilham Bahtera, is an Assistant Professor at Department of Agribusiness, University of Bangka Belitung, Indonesia. He graduated from Universiti Putra Malaysia, Selangor, Malaysia, 2016.

E-Mail: novyandra.ib@gmail.com.

3. Eddy Jajang Jaya Atmaja, is an Assistant Professor at Department of Agribusiness, University of Bangka Belitung, Indonesia. He graduated from Timbul Nusantara University, Jakarta, Indonesia, 2001.

E-Mail: eddyjajangjaya@gmail.com. 